This is an Accepted Manuscript of an article published by Taylor \& Francis in [Business history on 18 June 2020, available online: https://www.tandfonline.com/doi/abs/10.1080/00076791.2020.1769606?journalCode=fbsh20

\title{
The indigenous origins of UK corporate financial accountability: a comment.
}

Robin Pearson

University of Hull

The British liberal political tradition, which reached its apogee in the nineteenth century, prized publicity and detested secrecy, for the latter bred injustice and incompetence. ${ }^{1}$ This view was also frequently expressed in the corporate sphere. For some, the joint-stock form of enterprise offered a democratic ideal, a culture of openness and transparency that would ensure commercial honesty. Proponents of joint-stock banks, for instance, legitimised them by comparing joint-stock transparency with the culture of secrecy existing in private banks. ${ }^{2}$ For transparency to be effective, and for shareholders to perform their regulatory role, it was crucial that they had access to accurate information relating to their company's accounts. As one parliamentary committee asserted, full publicity of information 'would baffle every case of fraud'. Without this, it would be too easy for directors to run their companies in a despotic manner and squander the money entrusted to them.

Financial accountability was thus considered by many Victorians to be a key component of healthy corporate governance. Although debates over access to accounts dated back to the large chartered corporations of the late seventeenth century, including the Bank of England, such concerns multiplied in the railway age as stock companies grew in size and

1 See, for example, Jeremy Bentham, Rationale of Judicial Evidence (London: Hunt \& Clarke, 1827), i, c. 10; The Times 21. Sept.1850; Eugenio F. Biagini, 'Liberalism and Direct Democracy: John Stuart Mill and the Model of Ancient Athens', in Eugenio F. Biagini (ed.), Citizenship and Community: Liberals, Radicals and Collective Identities in the British Isles, 1865-1931 (Cambridge, 1996), pp. 21-44.

$2 \quad$ Anon., Remarks on the Objections to Joint Stock Banks (London, 1833), p. 19. 3 Report of the Select Committee on Joint-Stock Companies, Parliamentary Papers 1844 vii, p. v. 
attracted investment from ever-widening geographical areas, as shareholders lost their ability, or willingness, to act in a concerted manner, and as the information distance grew between them and the management of their companies. Between 1844 and 1862 milestone legislation was passed by the UK parliament that aimed to improve the financial reporting requirements of UK stock companies. Dr (A's...) article argues that this legislation owed its genesis - its 'legal origins' - to prior US and Canadian legislation. The article undertakes a diligent mapping of the financial reporting provisions in the 1862 UK Joint Stock Banks Act onto over 500 earlier acts in the other jurisdictions. This shows that some US financial accountability requirements, for instance those relating to statements of income and expenditure, appeared up to 50 years before the 1862 Act (p.14). It is suggested that this indicates that legislative ideas were transferred between former colonies and the UK (p.12), and that transatlantic regulation in this area had converged by the middle of the nineteenth century (p.23). The article thus extends the legal origins model of corporate governance by showing how outside regulatory regimes might help shape a country's laws and institutions (p.12).

Dr A's article performs a useful service in drawing the attention of business historians to the possibilities of the international transfer of regulatory practice. It is perfectly plausible that prior US and Canadian banking law may have influenced banking law in Victorian Britain. The question remains, however, about the extent of that influence? Just because early US bank charters contained financial reporting conditions does not mean that these had an impact on the provisions in subsequent UK acts, correlation not being equated to causation. Indeed, apart from a little evidence from Hansard in 1826 and 1836 indicating that British parliamentarians were aware of US banking regulations, and one reference to US banking laws made by the 1836 Select Committee, no other evidence for causality is presented in Dr 
(A's) article. Furthermore, by focusing on official sources and legislation, rather than the rules that companies established and operated in their everyday business, the article tells only a small part of the story of the early development of financial accountability in UK banking.

There were a number of ways in which companies could seek to ensure transparency in their affairs. As Freeman, Pearson and Taylor have shown, the constitutions of most UK joint stock companies before the middle of the nineteenth century specified several forms of access to accounts and at least one form of audit, the latter being usually carried out by a committee of shareholders elected by their general meeting, either on an ad hoc or regular basis. ${ }^{4}$ Despite the great variety of combinations of access and audit present in stock company constitutions, the majority required the board of directors to present annual summary accounts to the general meeting.

Certainly the managers of early joint stock banks valued secrecy and limited shareholders' access to company accounts and other documents more rigorously than was the case in other sectors of the UK corporate economy. However, British joint stock banks before 1826, with one exception, were all Scottish, as joint-stock banking in England was legally restricted to the Bank of England, and early Scottish banks did not operate in the same culture of secrecy as their successors. ${ }^{5}$ Both the Douglas Heron and Company Bank in Ayr (established 1772) and the Aberdeen Banking Company (1776), for example, permitted shareholders 'free Access and Liberty' to peruse the account books, albeit only in the

$4 \quad$ Mark Freeman, Robin Pearson and James Taylor, Shareholder Democracies? Corporate Governance in Britain and Ireland before 1850 (Chicago: University of Chicago Press, 2012). This comment draws on the research carried out for this book. The full dataset of joint-stock company constitutions, with sources, can be found in UK Data Archive, ref. SN5622, at http://www.data-archive.ac.uk.

$5 \quad$ The Bank of England's monopoly on joint stock banking in England was ended by the legislation of 1826 and 1833. See Ron Harris, Industrializing English Law: Entrepreneurship and Business Organization, 1720-1844 (Cambridge, 2000), pp. 211-15. 
presence of two directors. The constitution of the former also stipulated that the books would be inspected annually by shareholders at the company's general meeting. ${ }^{6}$ This relatively open system became increasingly restrictive after 1800. Few Scottish banks formed between 1809 and 1826 permitted shareholders the right of inspection outside the general meeting. In place of access to full accounts, bank constitutions now stipulated that balance sheets would be presented to general meetings. This was justified this by pointing to the fact that any breaches in customer confidentiality caused by excessive openness might be fatal to a bank's commercial success. $^{7}$

The period from 1827 to 1844 witnessed a convergence of accounting and audit provision among the new English and Scottish joint stock banks. None permitted individual shareholders access to accounts. ${ }^{8}$ Most specified that balance sheets would be presented to shareholders at the general meeting, but the form and contents of these were usually left to the discretion of the directors. ${ }^{9}$ Most also made provision for an ad hoc audit to be carried out by a committee of elected shareholders if the general meeting so ordered. ${ }^{10}$ Over time such audit committees became smaller in size, with higher share qualifications required for their members, arguably rendering them more easily manipulated by boards of directors. Although

\footnotetext{
6 Douglas Heron and Company Bankers in Ayr, Contract of Co-partnery, 31 January 1772, Glasgow University Archive Services, UGD129/4/4/2, pp. 23-4; Aberdeen Banking Company, Contract of Co-partnery, 1776, Bank of Scotland Archive, ABC 1/1/1, art. 9. 7 G. M. Bell, The Philosophy of Joint-Stock Banking ( $2^{\text {nd }}$ ed. London, 1855), p. 37. $8 \quad$ See, for example, Huddersfield Banking Company, Deed of Settlement (printed by J. Lancashire, Kirkgate, 1827), British Library BL 8226.dd.13.(4.), art. 52. An exception was made by the ruling in Hall $v$ Connell (1840), 3 Y\&C Ex 707, for shareholders involved in a suit against their company.

$9 \quad$ See, for example, Huddersfield Banking Company, Deed of Settlement, art. 20.

10 In most cases, a simple majority was required, but the Hull Banking Company made it harder for the shareholders to appoint auditors, requiring a two-thirds majority: Hull Banking Company, Deed of settlement, 23 October 1834, printed W. Kennedy, Hull, 1834: British Library, RB.23 a.17862, art. 79.
} 
the constitutions of most new banks continued to require balance sheets to be presented to the general meeting of shareholders, at least two made no explicit provision even for this. ${ }^{11}$

The series of UK legislation that commenced with the Joint Stock Companies Act of 1844 went some way towards standardising the governance provisions of joint-stock companies, but it largely formalised or extended what had already become common practice. ${ }^{12}$ The act of 1844 to regulate English joint-stock banks required that the assets and liabilities of companies be published at least once a month, that the accounts be audited once a year by two or more auditors, not being directors, chosen at the general meeting, and that the auditors' report, balance sheet, and profit and loss account be communicated annually to every shareholder. ${ }^{13}$ The following year saw two near identical acts for the consolidation of clauses of acts of incorporation applied, respectively, to Scotland and England. ${ }^{14}$ These stipulated that shareholder and loan registers and accounts be available for the inspection of shareholders. ${ }^{15}$ Directors were required to make up 'an exact Balance Sheet... which shall exhibit a true Statement of the Capital Stock, Credits, and Property of every Description belonging to the Company, and the Debts due by the Company at the Date of making such Balance Sheet, and a distinct View of the Profit or Loss which shall have arisen on the Transactions of the Company in the course of the preceding Half Year'. ${ }^{16}$ This was to be produced at the general meeting, together with the auditor's report. ${ }^{17}$ Auditors, who were to be shareholders but not directors, were to be appointed at the general meeting, and rotated

11 These were the Sheffield and Rotherham Joint Stock Banking Company (1836) and the Royal Bank of Australia (1840).

$12 \quad 7 \& 8$ Vict. c. 110 , art. 37.

$137 \& 8$ Vict. c. 113 , art. 4.

148 Vict. cc. 16-17.

158 Vict. c. 16 , arts. $10,45,98,117$.

16 Ibid., art. 116.

17 Ibid., art. 118. 
annually. ${ }^{18}$ These regulations embodied a traditional view of joint-stock politics in which shareholders were empowered to ensure that directors were held accountable. Yet this conception of companies as self-regulating entities was beginning to weaken. The very existence of the legislation pointed to an increasing conviction that external forces had to be brought to bear on companies to ensure that they were governed honestly and efficiently. Some looked to the press, others to the government, to complement or replace functions traditionally performed by shareholders.

The above account suggests that the major influence on banking financial accountability provisions in UK acts after 1844 was the existing practice of English joint stock companies, as well as the influence of Scottish and Irish banks, rather than prior legislation from foreign jurisdictions. The constitutional template provided in the 1845 Companies Clauses Act was designed to reflect the existing constitutions of stock companies, including their provisions for financial reporting. It is true, as $\operatorname{Dr}(\mathrm{A})$ points out, that the 1826 Country Bankers Act 'remained silent on provisions of financial accountability' (p.4), but that is not true of the constitutions of the new provincial banks that appeared after that act, and in any case it was not the purpose of the 1826 act to establish model governance provisions. The 1844 legislation about mandatory balance sheets only reflected widespread existing practice by stock companies in banking and many other sectors. In the English corporate legal environment before 1844, unlike the US with its state chartered corporations and general incorporating acts, there was less emphasis on external regulation for the sake of salus populi, and far more emphasis on self-regulation by companies through their constitutions and by-laws, which provided shareholders with monitoring powers over their executives, and which most accorded with liberal ideals. Parliamentary moves to legislate for

18 Ibid., arts. 101-8. 
financial accountability were a belated recognition of long-established expectations in the corporate world of the rights and responsibilities of shareholders.

My argument that UK corporate laws on financial accountability and other aspects of corporate governance drew primarily on existing 'voluntary' practice in business is actually supported by other authorities referenced by $\operatorname{Dr}$ (A him/herself) on p.12, where Acheson et al are cited as concluding that '...many of the protections afforded to shareholders during the voluntary era were subsequently adopted in mandatory legislation...' and again on p.11 where '...in Britain private contracts between shareholder and corporation created an efficient instrument of accountability and therefore statutory regulation was less relevant...[than in the US]'. Furthermore, it is claimed p.25 that 'financial accountability varied across the period examined, increasing significantly in later years', and yet, as noted above, almost all English joint stock banks established between 1827 an 1844 had rules embedded in their constitutions requiring directors to present annual balance sheets at general meetings and made provision for audits. US and Canadian laws may have been considered by those debating British banking reform in the 1830s, but the main influence on UK banking financial accountability legislation of the 1840 s through the 1860 s was almost certainly indigenous market practice. 